parts. The under parts are generally of a deep green or bluish, irrespective of the insect's habitat. These colors do not show from above. On this account many of the species seem to be more brightly colored beneath than above, except in such cases as afford the bright colors above a chance to assimilate with soils or foliage. Yet the upper parts are really the more richly colored in all the species, though they may not appear so to the causal eye. Here, in the coloration of the upper parts of the Cicindelce, natural and sexual selection blend. They act together at the same time upon the same parts. While sexual selection produces beautiful tints, natural selection takes care that none remain that will endanger the insects preservation by making it conspicuous in its retreats. In this way colors, which otherwise would be prominent, assume a general dull appearance, which will not arrest the eye. Life is of primary value, but so also is beauty to the perpetuation of the insect. While the upper parts retain the colors that will assimilate well with their surroundings, sexual selection has given them tints, which though in many cases seemingly dull to the eyes of man, are found under a high lens to consist of the most lovely bronzed, purplish and dazzling green reflections, in the entirety of which beauty the insects appear to themselves by virtue of their far superior sight development.

\title{
LARVA OF SEIRODONTA BILINEATA, PACK.
}

BY G. H. FRENCH, CARBONDALE, ILL.

Length $\mathrm{T} .20$ inches; cylindrical, rather slender, two warty elevations on the dorsum of joints 5 and 12 , elsewhere the piliferous spots scarcely perceptible, except for the single hair that arises from each. Color green; a dorsal pale yellow line, bordered on each side on joints 3 and 4 by a purple line; outside this a pale yellow stripe that diverges on joint 2 , gradually diverging again on joints 4,5 and 6 , where it reaches below the usual region of the subdorsal line, extending from this back to joint $\mathrm{I} I$, from which it gradually converges to the elevations on joint $\mathbf{I} 2$, touching these on the outside, the diverging and converging referring to the stripes on both sides of the body. These stripes send more or less prominent deflections down the sides of joints 7 and ro. In some examples the space between these stripes and the dorsal line contains a pale whitish stripe each side of the dorsal ; the deflections, and a little on joint 5 and 
the elevations, are reddish purple. In other examples the whole space between the lines, except four or five greenish patches, is reddish purple, there being various intergrades. In all cases the purple is mottled. The sides are specked with purple; stigmatal line yellow with traces of one above this. Head with a dark purple line each side, outside of which is a yellowish line.

The larvæ from which this description was taken, I3 in all, were taken on a young elm tree September $29, \mathbf{1} 884$. By October 5 th all but one had disappeared for the purpose of pupation, going beneath the surface of the dirt in the breeding cage. Nine imagines were produced the following spring, the times of emergence ranging from May 24th to June 7 th. There seems to be two broods in a season, for larva were found on elms during the early part of summer, but these were not reared to find out the period of the summer brood.

\section{NOTES ON PAPILIO TURNUS AND PYRAMEIS CARDUI.}

BY MRS. C. H. FERNALD.

Previous to the summer of. 884 , Papilio turnus and Pyrameis cardui had been quite rare in Orono, Me, and vicinity, not more than half a dozen of the former and two or three of the latter having been seen each year; but in June of that year P. tumus was so abundant that it was not uncommon to see a dozen or more flying together. In August of the same year fresh specimens of $P$. cardui were so abundant that in a small piece of red clover, not more than two rods from the house, I captured twenty-five in half an hour, and the numbers were not perceptibly diminished. The next day they were equally abundant, but the following day we had a cold rain storm, after which only a very few poor, faded examples were seen. The next summer (1885) P. turnus was again rare, and not one example of $P$. cardui was seen by myself, nor by any one in this vicinity. Parasites might have made the difference in the number of $P$. turnus, but could they have done so with that immense number of $P$. cardui, or did that storm so effectually destroy them before laying their eggs that there were none the next year, or is it possible that some epidemic attacked them, leaving none to perpetuate the race? We can understand the gradual increase and decrease of certain species which is noticeable every year, but the sudden abundance and scarcity of some 